\author{
Monika Wiszniowska (iD https://orcid.org/0000-0002-3018-0466 \\ Uniwersytet Śląski \\ monika.wiszniowska@us.edu.pl
}

\title{
Dom z dwiema wieżami Macieja Zaremby Bielawskiego jako „arcypolska opowieść reporterska napisana po szwedzku"1
}

\section{Maciej Zaremba's Huset med de två tornen as an "Arch-Polish Reportage Story Written in Swedish"}

\begin{abstract}
Maciej Zaremba-Bielawski is one the leading Swedish publicists and writers of Polish origin, a reporter of the well-known Stockholm newspaper Dagens Nyheter, a prizewinner of prestigious Scandinavian journalist awards and peace prizes. He is a well-read and wellacknowledged author in Poland as well; all of his books are accessible to the Polish readership. The article investigates the influence of features characteristic for the Polish school of reportage on the oeuvre of the author of De rena och de andra: om tvangssteriliseringar, rashygien och arvsynd (On Eugenic Sterilisations in Sweden and elsewhere), in particular in connection with his latest book titled Huset med de tva tornen (A House with Two Turrets). Firstly, the article attempts to identify its genre traits, leaning towards the claim that it is a literary reportage woven around an autobiographic tale. Secondly, the article tries to highlight these traits of Huset med de tva tornen which confirm the thesis about the literary character of reportage and the use of patterns developed by the Polish authors of reportage books. The literary character of the discussed book is noticeable in the humanist approach of the author, understood as the reflection not only on the condition of humankind and world, but also on his own attitude towards the topic, as well as posing deliberate questions about the place and the role of values in the world. It is seen in the deliberation contained in Huset med de tva tornen, which is a multidimensional reflection on Polish history, fate of the Polish Jews, anti-Semitism as well as first and foremost memory.
\end{abstract}

Keywords: Maciej Zaremba-Bielawski, literary reportage, axiology, history, memory

${ }^{1}$ Określenie książki Macieja Zaremby Bielawskiego zaczerpnęłam z wypowiedzi Julii Fiedorczuk przygotowanej z okazji wręczenia autorowi Nagrody im. Ryszarda Kapuścińskiego. Zob. J. Fiedorczuk, Tylko trzy stowa, http://www.kulturalna.warszawa.pl/kapuscinski,6,11027.html, dostęp: 17.03.2021. 
Streszczenie: Maciej Zaremba Bielawski jest jednym z czołowych szwedzkich publicystów i literatów polskiego pochodzenia, reporterem znanego sztokholmskiego dziennika „Dagens Nyheter", laureatem prestiżowych skandynawskich konkursów dziennikarskich i wyróżnień pokojowych. Jest też w Polsce autorem poczytnym i uznanym, wszystkie jego książki zostały udostępnione polskiej publiczności. W swoim artykule przyglądam się oddziaływaniu cech polskiej szkoły reportażu na twórczość autora Higienistów, w szczególności na kształt jego ostatniej książki zatytułowanej Dom z dwiema wieżami. Najpierw próbuję wskazać jej wyróżniki gatunkowe, skłaniając się ku twierdzeniu, iż mamy do czynienia z reportażem literackim osnutym wokół opowieści autobiograficznej. W drugiej kolejności staram się uwypuklić te cechy Domu z dwiema wieżami, które potwierdzają tezę o literackości reportażu i korzystaniu z wzorów wypracowanych przez polskich autorów książek reportażowych. Literackość omawianej książki dostrzegam w postawie humanistycznej autora, rozumianej jako refleksja nad kondycją człowieka i świata, a także nad własnym stosunkiem do tematu, jako świadome zadawanie pytań o miejsce i rolę wartości w świecie. Widzę ją w zawartej w Domu $z$ dwiema wieżami refleksji, w wielowymiarowym namyśle nad polską historią, nad losem polskich Żydów, antysemityzmem, ale przede wszystkim nad pamięcią.

Słowa kluczowe: Maciej Zaremba Bielawski, reportaż literacki, aksjologia, historia, pamięć

Maciej Zaremba Bielawski jest jednym z czołowych szwedzkich publicystów i literatów polskiego pochodzenia, reporterem znanego sztokholmskiego dziennika „Dagens Nyheter”, laureatem prestiżowych skandynawskich konkursów dziennikarskich i wyróżnień pokojowych ${ }^{2}$. Zanim na rynku księgarskim pojawił się Dom $z$ dwoma wieżami $i^{3}$, polscy czytelnicy mogli poznać twórczość reportera już w 2008 roku, obcując ze zbiorem reportaży pod tytułem Polski hydraulik i inne opowieści ze Szwecji (wznowiony i uzupełniony w 2013 roku). Dobre przyjęcie książki zaowocowało wydaniem w roku 2011, ważnej dla szwedzkiego odbiorcy, ale rozbudowanej o kontekst polski, w tym o działalność ojca autora, pozycji Higieniści. $Z$ dziejów engeniki ${ }^{5}$, którą autor zdobył popularność w Szwecji już

${ }^{2}$ Za swoje artykuły Maciej Zaremba Bielawski otrzymał między innymi kilkakrotnie Nagrodę Akademii Szwedzkiej, Wielką Nagrodę Dziennikarską - za cykl Polski hydraulik, a gazeta „Land” w plebiscycie wybrała go „Królem Lasu” za Leśna mafię.

${ }^{3}$ M. Zaremba Bielawski, Dom z dwiema wieżami, tłum. M. Kalinowski, Kraków 2018. Książka ta została napisana w języku szwedzkim i mistrzowska przetłumaczona na język polski przez Mariusza Kalinowskiego, który także został laureatem Nagrody im. Ryszarda Kapuścińskiego za najlepsze tłumaczenie reportażu literackiego 2019 roku [na oznaczenie tego wydania w dalszej części tekstu będę używała skrótu DW ze wskazaniem odpowiedniego numeru strony].

${ }^{4} \mathrm{M}$. Zaremba Bielawski, Polski hydraulik i inne opowieści ze Szwecji, tłum. W. Chudoba, J. Rost, A. Topaczewska, K. Tubylewicz, Wołowiec 2008; tenże, Polski hydraulik i nowe opowieści ze Szwecji, tłum. W. Chudoba, J. Rost, A. Topaczewska, K. Tubylewicz, Warszawa 2013.

${ }^{5}$ Tenże, Higieniśsi. Z dziejów engeniki, thum. W. Chudoba, Wołowiec 2011. 
1999 roku. Kilka lat później na półkach księgarskich pojawiła się jeszcze książka Leśna mafia. Szwedzki thriller ekologiczny $(2014)^{6}$.

Sukces Zaremby Bielawskiego na szwedzkim rynku wynika nie tylko z faktu umiejętnego dostosowania reporterskiego warsztatu do miejscowych warunków. Nie bez znaczenia jest, wielokrotnie podkreślany przez reportera, dystans, który mający źródło w potrójnej polsko-szwedzko-żydowskiej tożsamości. Autor Higienistów urodził się w Polsce, ale wyjechał do Szwecji w wieku 18 lat wraz z braćmi, babcią i matką Żydówką pod wpływem antysemickiej kampanii, zapoczątkowanej wydarzeniami Marca 1968 roku $^{7}$ „ „[N]ic tak nie ogłupia jak swojskość" - powiedział w jednym z wywiadów, potwierdzając tym samym obserwacje innych polskich reportażystów, którzy często wskazywali, że to właśnie dystans wynikający z obserwacji, bycie jakby „na zewnątrz”, daje możliwość znalezienia ważnych punktów odniesienia, porównań ${ }^{8}$.

Z perspektywy lektury Domu z dwiema wieżami mniej ważne jest „polskie” oddalenie Macieja Zaremby Bielawskiego od szwedzkiej rzeczywistości. Ważniejsze okazują się przeszłość emigracyjna reportera, jego zakorzenienie w szwedzkim języku, słowem, „szwedzka” odległość od spraw polskich. Być może zanurzenie w szwedzkiej publicystyce sprawiło, iż szybko dostrzegł autor Higienistów „inność, ale przede wszystkim wartość polskiego reportażu literackiego. Zaremba Bielawski wielokrotnie mówił o swojej fascynacji polską twórczością reportażową. W jednym z wywiadów wprost deklaruje:

Od lat rozczytuję się w polskim reportażu, tak bardzo odmiennym od szwedzkiego, o innej optyce, głębszej wrażliwości... I tę inność chciałem pokazać. Być może chodziło też o to, żeby się przedstawić - skąd pochodzę, z jakiej tradycji... Ogromnie dużo zawdzięczam Kapuścińskiemu i Hannie Krall. Wydaniem Uwertury do życia staram się więc spłacić także ten dług9.

Dług Maciej Zaremba Bielawski spłacił z nawiązką, najpierw wydając Uwerturę do życia, zredagowaną przez siebie w 2003 roku szwedzkojęzyczną antologię polskiego reportażu, a po kilkunastu latach napisał, korzystając z wieloletnich

${ }^{6}$ Tenże, Leśna mafia. Szwedzki thriller ekologiczny, tłum. M. Wasilewska-Chmura, Warszawa 2014.

${ }^{7} \mathrm{Na}$ znaczenie potrójnej tożsamości Zaremby Bielawskiego zwracali uwagę: Katarzyna Frukacz i Michał Kopczyk. Zob.: K. Frukacz, Szwedzki Polak - polski Szwed. Maciej Zaremba Bielawski wobec polskości i polskiej szkoty reportażu [w:] Literatura polska w świecie, t. 7: Reportaż wświecie. Światowość reportażu, red. K. Frukacz, Katowice 2019; M. Kopczyk, Hermeneutyka pamięci. $O$ „Domu z dwiema wieżami” Macieja Zaremby Bielawskiego, „Białostockie Studia Literaturoznawcze" 2020, nr 17.

${ }^{8}$ Dla przykładu Jacek Hugo-Bader tak deklarował w jednym z wywiadów: „Jak jesteś za bardzo u siebie, to tracisz ostrość widzenia”. Zob. Portret Badera. Z Jackiem Hugo-Baderem rozmawia Piotr Brysacz [w:] Patrzac na Wschód. Przestrzeń, cztowiek, mistycyzm, Białystok 2013, s. 76.

${ }^{9}$ Czego nam zazdroszcza Szwedzi?, rozmowe z Maciejem Zaremba Bielawskim przeprowadzit G. Sokót, „Gazeta Wyborcza” 2003, nr 272 [dodatek: „Książki”, nr 11(2)], s. 6. 
doświadczeń autorów polskiej szkoły reportażu ${ }^{10}$, arcypolską opowieść Dom $z$ dwiema wieżami. Sam autor Higienistów, po otrzymaniu Nagrody im. Ryszarda Kapuścińskiego za tę właśnie książkę, przyznał, że ona „nie powstałaby, gdyby nie polska szkoła reportażu. - Nie chodzi tylko o pisanie, ale też o uparte poszukiwanie szczerości. Nauczyłem się jej od Ryszarda Kapuścińskiego, Hanny Krall i Małgorzaty Szejnert" ${ }^{\prime 1}$.

Zatrzymajmy się na chwilę przy wspomnianej antologii. Warto zauważyć, że większość tekstów w niej zamieszczonych to w dużej mierze reportaże autorów związanych, na jakimś etapie kariery zawodowej, z „Gazetą Wyborczą, która przez długi czas od powstania gazety pielęgnowała reportaż literacki. Pozycje, które wybrał Zaremba Bielawski, napisali obdarzeni świetnym piórem reporterzy, zdobywający swoje pierwsze szlify pod okiem najpierw Hanny Krall, a potem Małgorzaty Szejnert - wszystkie charakteryzują się wysokim stopniem literackości ${ }^{12}$.

Rozczytujący się w polskim reportażu literackim Zaremba Bielawski szwedzkiemu czytelnikowi objawił się przede wszystkim jako sprawny publicysta. Dominację żywiołu publicystycznego w reportażach autora Higienistów dostrzega również Katarzyna Frukacz, choć nieco na wyrost, moim zdaniem, przypisuje im też walory literackie. Badaczka zalicza do nich: fabularyzowanie przekazu, wplatanie dialogów oraz umiejętne zawiązywanie i dynamizowanie akcji przez dozowanie ujawnianych informacji ${ }^{13}$. Są to przecież atrybuty także dobrze skrojonego tekstu publicystycznego. Poza wspomnianą książką o eugenice o charakterze popularnonaukowym zarówno zbiór reportaży Polski hydraulik i inne opowieści ze Szwecji, jak i Leśna mafia mają wyraźny wymiar publicystyczny. To bardzo interesujące i sprawnie napisane reportaże interwencyjne, mające na celu przede wszystkim uświadamianie społeczeństwa, poprzez opisywanie istotnych dla niego zjawisk, a także wykrywanie i eliminowanie nieprawidłowości życia publicznego. I choć, po koleżeńsku, Mariusz Szczygieł na okładce Polskiego hydraulika przypisuje Zarembie Bielawskiemu „czerpanie z tradycji polskiego reportażu literackiego ${ }^{14}$, to zdecydowanie skłaniam się ku opinii, wyrażonej na okładce

${ }^{10}$ Kategoria „polskiej szkoły reportażu” nie jest w sposób jednoznaczny określona. Wnioskując z różnorodnych wypowiedzi Zaremby Bielawskiego, ma on na myśli model reportażu literackiego. Próbowałam go opisać w książce: M. Wiszniowska, Zobaczyć - opisać - zrozumieć. Polskie reportaże literackie o rosyjskim imperium, Katowice 2017.

${ }^{11}$ Wypowiedź Macieja Zaremby Bielawskiego po otrzymaniu Nagrody im. Ryszarda Kapuścińskiego za reportaż literacki, zob. https://wyborcza.pl/7,75517,24816362,nagroda-kapuscinskiego-2019-dla-macieja-zaremby-bielawskiego.html, dostęp: 24.05.2019.

${ }^{12}$ Antologia zawiera między innymi następujące teksty, które zostały wydrukowane w książkach: Wrajskiej dolinie wśród zielska Jacka Hugo-Badera, Wieże z kamienia Wojciecha Jagielskiego, Obwód gtowy Włodzimierza Nowaka, Cygan to Cygan Lidii Ostałowskiej, Gottland Mariusza Szczygła oraz Schodów się nie pali i Jakbyś kamień jadta Wojciecha Tochmana. Informacje o antologii podaję za: K. Frukacz, dz. cyt., s. 108.

${ }^{13}$ K. Frukacz, dz. cyt., s. 109.

${ }^{14}$ Mariusz Szczygieł tak napisał na okładce książki Zaremby Bielawskiego: „Kiedy w pierwszym rozdziale przeczytałem pierwsze zdanie (»Tego październikowego popołudnia stolarz Jan 
Leśnej mafii przez niemieckiego dziennikarza Thomasa Steinfelda, że: „Maciej Zaremba jest najlepszym szwedzkim reporterem interwencyjnym"15.

Choć, jak wspomniałam, trudno byłoby mi wskazać owo czerpanie z tradycji polskiego reportażu we wspomnianych tekstach publicystycznych Zaremby Bielawskiego, autor, powtórzmy raz jeszcze, zna ją dobrze i ceni wysoko. Dodatkowo sam, zarówno we wstępie do wspomnianej antologii, jak i w wielu wypowiedziach dla polskiej prasy, często przywołuje i omawia jej cechy. Chciałabym więc, przede wszystkim, przyjrzeć się, na jakie wyznaczniki polskiej szkoły reportażu zwraca uwagę autor Higienistów, by później móc wskazać oddziaływanie cech polskiego reportażu literackiego na Dom z dwiema wieżami.

Przyczyn wyjątkowości polskiego reportażu Zaremba Bielawski upatruje paradoksalnie w istnieniu cenzury i tego, co w latach sześćdziesiątych XX wieku nazywano w literaturze „małym realizmem”. „Wyjątkowa jakość polskiego reportażu - pisze reporter - do tej pory znanego w Szwecji tylko z książek Hanny Krall i Ryszarda Kapuścińskiego - jest paradoksalnie konsekwencją cenzury, która przez ponad czterdzieści lat czyniła z dziennikarstwa zajęcie dla paziów i agentów"16. Choć nie jest to twierdzenie bezzasadne, jego upraszczający charakter możemy złożyć na karb krótkiej, chwytliwej, przeznaczonej dla szwedzkiego czytelnika, wypowiedzi. Ważniejsze dla nas w tym miejscu jest wskazanie cech, które Zaremba Bielawski dostrzega w wybranych przez siebie reportażach. We wstępie do wspomnianej antologii zwraca uwagę na to, co w nich „niewypowiedziane i tajemnicze, i co świadczy o przekonaniu autorów, że żadnego człowieka, jakkolwiek nieznaczącego, nie można zamknąć w jednej formule albo uczynić wyłącznie pokazowym przykładem" ${ }^{17}$. Autor Higienistów trafnie konstatuje, że w twórczości autorów polskiego reportażu literackiego dominuje „renesansowe przekonanie o pojedynczym ludzkim losie jako mierze społeczeństwa"18.

Nie ulega wątpliwości, że dla Hanny Krall, Małgorzaty Szejnert, Wojciecha Tochmana, Mariusza Szczygła czy Wojciecha Jagielskiego, by wymienić kilku najważniejszych reportażystów, to odkrywanie mikrokosmosu, małych światów „innych ludzi”19 prowadzi do poznania świata. Trafnie dostrzega też Zaremba Bielawski, że bycie świadkiem, to nie tylko dokładność w opisie tego,

Andersson w obecności żony stracił panowanie nad sobą «), już wiedziałem, że mamy do czynienia nie tylko ze sprawnym publicystą, ale z reportażystą, który czerpie z tradycji polskiego reportażu literackiego". Zob. M. Zaremba Bielawski, Polski hydraulik i inne opowieści ze Szwecji, dz. cyt., okładka, s. 4.

${ }^{15}$ M. Zaremba Bielawski, Leśna mafia, dz. cyt., okładka, s. 4.

${ }^{16}$ Tenże, Dziennikarz jest świadkiem, tłum. G. Sokól, „Tygodnik Powszechny” 2009, nr 23 [dodatek: „Festiwal Conrada 2009”], s. 12-13. Cytowany tekst jest przekładem przedmowy do antologii Ouvertyr till livet.

${ }^{17}$ Tamże.

${ }^{18}$ Tamże.

${ }^{19}$ Zob. E. Domańska, Mikrohistorie. Spotkania w międzyświatach, Poznań 2005. 
co się widzi, ale właściwy poetom szacunek do tego, czego zrozumieć nie sposób $^{20}$. W tym zdaniu widać wnikliwą lekturę tekstów przede wszystkim Hanny Krall. To w reportażach autorki Dowodów na istnienie obcujemy z tajemnicą, jakimś rodzajem przeżycia metafizycznego, obietnicą nigdy nieosiągalnej prawdy.

Jest jeszcze jedna cecha polskiego reportażu literackiego, którą dostrzega autor Domu z dwiema wieżami. Pisze, że wartość dla niego mają „reportaże napisane z pozycji tej pokory wobec względności osobistych prawd"21. To bardzo ważne zdanie, przywołujące dwie istotne kwestie. Po pierwsze, o wartości polskiego reportażu w dużej mierze decyduje wspomniana przez Zarembę Bielawskiego pokora, świadomość tego, że świat jest do końca niepoznawalny, a zadaniem reportera jest jedynie próba przeniknięcia, zrozumienia rzeczywistości, którą opisuje. Po drugie, autor Higienistów wskazuje na jeden z najważniejszych wyznaczników reportażu literackiego: kwestię podmiotu opowiadającego. Do tematu przyjdzie jeszcze powrócić, w tym miejscu zasygnalizuję jedynie, że Zaremba Bielawski trafnie dostrzegl, iż cechą wspomnianych tekstów reportażowych jest wyjątkowa postawa reportera-świadka, w której zawiera się specyficzna kompilacja dystansu i uczestnictwa.

Stale obserwujący dokonania polskich reporterów, dodatkowo wyposażony w przedstawiony powyżej „model” reportażu literackiego, Maciej Zaremba Bielawski został zaproszony najpierw do kapituły Nagrody im. Ryszarda Kapuścińskiego, a potem (2014-2016) do jej przewodniczenia. Jako juror, nie tylko chwalit, ale także wskazywał wady niektórych, zgłoszonych do konkursu tekstów. Dostrzegał - niestety coraz bardziej powszechne zjawisko - reportaże napisane językiem sensacji albo wabiące tanią egzotykąa ${ }^{22}$. Co ciekawe, zapytany wówczas o nominacje wspomniał dziennikarce przeprowadzającej z nim wywiad, że kilka książek, w tym interesujące biografie, ze względów formalnych nie weszły do konkursu. W grupie tej była Stryjeńska. Diabli nadali (2019) Angeliki Kuźniak. Jakie kryteria kazały kapitule odrzucić tę książkę - trudno orzec, biorąc choćby pod uwagę fakt, że dwa lata wcześniej nagrodzona zostaje opowieść o okupacji, widziana oczyma Anny Bikont w książce o Irenie Sendlerowej (Sendlerowa. W ukryciu), nazwaną przecież „biografią na pograniczu reportażu” (nagroda 2017). Sprawa komplikuje

${ }^{20}$ M. Zaremba Bielawski, Dziennikarz jest świadkiem, dz. cyt.

${ }^{21}$ Tamże, s. 12-13.

${ }^{22}$ Proszę nie tracać mnie tokciem w bok. Z Maciejem Zaremba Bielawskim rozmawia A. Szytto, „Gazeta Wyborcza”, 10.03.2016 [dodatek: „Duży Format”].

${ }^{23}$ Polska to europejski fenomen. W żadnym innym kraju reportaż nie jest tak bardzo sexy. Dlaczego?Z Maciejem Zarembą Bielawskim rozmawia Anna S. Dębowska, „Gazeta Wyborcza”, 23.05.2019. 
się jeszcze bardziej, gdy sam przewodniczący jury dostanie w 2019 roku główną nagrodę za... reportaż autobiograficzny.

Ta niekonsekwencja ilustrująca w dużej mierze zmiany genologiczne w obrębie reportażu literackiego warta jest osobnego studium, w tym miejscu, ze względu na nieoczywistość gatunkową Domu z dwiema wieżami, chciałam jedynie tę kwestę zasygnalizować. Przywołajmy ustalenia Małgorzaty Krakowiak, która wykorzystując politypiczny model myślenia o gatunku Ireneusza Opackiego, pisze:

kiedy dominującym gatunkiem był esej literacki, obserwowalna była eseizacja również reportażu, co zaowocowało m.in. Imperium oraz Hebanem Ryszarda Kapuścińskiego. Ostatnimi czasy główną rolę w produkcji pisarskiej odgrywają biografie i właśnie cechami biografii nasycone zostały utwory, którym nie tylko z tego powodu warto przyjrzeć się bliżej - Wszystkie wojny Lary Jagielskiego, nota bene wywodzącego się ze „szkoły Kapuścińskiego”, oraz Synapsy Marii H. Hanny Krall ${ }^{24}$.

Czy nasycenie reportażu watkami autobiograficznymi będzie kolejną tendencją w przemianach tego gatunku? Nie wydaje się to możliwe. Możemy przypuszczać, że niewielu reporterów uzna własny fragment biografii bądź losy własnej rodziny za materiał na tyle ważny i interesujący, by zainspirował ich do napisania książki.

W przypadku Macieja Zaremby Bielawskiego, trudno o ciekawszy materiał na literaturę niż życiorys reportera i jego bliskich. Wystarczy wspomnieć o dwóch najważniejszych postaciach tej książki. Najpierw o ojcu: Oskarze Bielawskim urodzonym w Homlu na początku ostatniej dekady XIX wieku, w szacownej rodzinie szlacheckiej, zdeklasowanej w okresie rozbiorów. Był on uczestnikiem pierwszej wojny światowej, studentem medycyny w Dorpacie, jednym z najznamienitszych polskich psychiatrów. Jego imię dziś nosi sanatorium w Kościanie, którym zarządzał w dwudziestoleciu międzywojennym najbardziej nowoczesnymi i humanitarnymi metodami. Materiałem na osobną książkę mógłby być także życiorys matki: kobiety o wielu imionach (Lila, Elżbieta, Iza), młodszej od męża o trzydzieści lat, córki przedwojennego sędziego Izaaka (Wilhelma) Immerdauera. Wychowana w zasymilowanej żydowskiej rodzinie, z powodu obowiązującego wówczas numerus nullus, w 1938 roku nie mogła zrealizować swoich ambicji i studiować medycyny. Wojnę udaje jej się przeżyć dzięki cudownemu ocaleniu z rąk nieznajomych osób. Po wojnie, już jako pani doktor, specjalistka od psychiatrii dziecięcej, znowu okazuje się „elementem niepożądanym", więc wraz z synami emigruje do Szwecji.

Trudno się więc dziwić, że kiedy zajrzymy na stronę wydawnictwa „Karakter", dowiemy się, że Dom $z$ dwiema wieżami to fascynująca próba rekonstrukcji

${ }^{24}$ Dziękuję Małgorzacie Krakowiak za udostępnienie maszynopisu nieopublikowanego tekstu Neofabulacja w pisarstwie polskich reportażystów („Wszystkie wojny Lary” Wojciecha Jagielskiego $i$ „Synapsy Marii H.” Hanny Krall). 
rodzinnej historii, która dotąd pełna była przemilczeń ${ }^{25}$. W mniej lub bardziej profesjonalnych recenzjach przeważa charakterystyka tej książki jako autobiograficznej, rodzinnej opowieści. Nierzadkie jest również zdziwienie, że została ona nazwana reportażem, jak choćby w recenzji Stanisława Obirka: „Moim zdaniem to jest bardziej autobiografia literacka niż reportaż"26. Trudności genologiczne potwierdza także wypowiedź Marcina Wichy: „Wspomnienie chłopca zamienia się w sagę rodzinną, w esej historyczny, w reportaż śledczy, w panoramę. Ale to wciąż jest osobiste"27. Nie mniej kłopotu mają badacze. Edyta Żyrek-Horodyska, określając książkę Zaremby Bielawskiego jako reportażową sagę rodzinną, pisze:

W omawianym tu tomie, stanowiącym nowe wcielenie reportażu, zdecydowanie dominuje postawa autobiograficzna, wyrażająca się poprzez narrację pierwszoosobową, intencjonalnie uwypuklającą rolę narratora-bohatera jako osoby będącej spadkobiercą rodzinnej historii, swoistym depozytariuszem wspomnień i głosem tych, którym zostało odebrane prawo do mówienia ${ }^{28}$.

Poza wskazaniem postawy autobiograficznej badaczka pisze też o „nowym wcieleniu reportażu". W podobnym tonie klasyfikuje tom Zaremby Bielawskiego Julia Fiedorczuk, jurorka X edycji Nagrody im. Ryszarda Kapuścińskiego, nazywając go "nowym rodzajem osobistego reportażu” ${ }^{29}$. Ani Żyrek-Horodyska, ani Fiedorczuk nie tłumaczą, na czym owa nowość polega, warto więc w tym miejscu podkreślić, że Zaremba Bielawski nie jest pierwszym autorem, który buduje opowieść reporterską na kanwie własnej biografii. Wystarczy tu przywołać choćby pierwszy rozdział Imperium ${ }^{30}$, w którym Kapuściński opowiada o swoich latach dzieciństwa spędzonych w Pińsku, czy Sezon na stoneczniki Igora T. Miecika ${ }^{31}$, który wykorzystuje poetykę sagi rodzinnej, by opowiedzieć o trudnym i ciągle trwającym procesie dekolonizacji ukraińskiego narodu.

Przypomnijmy w tym miejscu, że dla Zaremby Bielawskiego polska szkoła reportażu to przede wszystkim Hanna Krall, Ryszard Kapuściński i Małgorzata Szejnert, polscy reportażyści reprezentujący nota bene to samo pokolenie, autorzy wybitni, mający na swoim koncie nie tylko ważne pozycje książkowe, ale także wielu uczniów, następców twórczo kontynuujących wypracowany przez swoich mistrzów model reportażowego pisania. Nie zapominajmy jednak, że ojcem

\footnotetext{
${ }^{25}$ M. Zaremba Bielawski, Dom z dwiema wieżami, dz. cyt., okładka, s. 4.

${ }^{26}$ S. Obirek, Dom z dwiema wieżami - ksiażka na czasie, https://studioopinii.pl/archiwa/199021, dostęp: 20.06.2020.

${ }^{27}$ M. Wicha, Mama powiedziata: „Wyjeżdzamy. Jestem Żydówką. Nowa ksiązka Zaremby Bielawskiego jest jak operacja na samym sobie, „Gazeta Wyborcza”, 4.12.2018, s. 19.

${ }^{28}$ E. Żyrek-Horodyska, Reportażowa saga rodzinna. Fuzja gatunków i dziennikarska archiwistyka, „Zeszyty Naukowe KUL” 2019, nr 4, s. 140-141.

${ }^{29} \mathrm{~J}$. Fiedorczuk, dz. cyt.

${ }^{30}$ Zob. R. Kapuściński, Imperium, Warszawa 1993.

${ }^{31}$ Zob. I.T. Miecik, Sezon na stoneczniki, Warszawa 2015.
} 
polskiego reportażu literackiego jest Melchior Wańkowicz, który, w swojej słusznych rozmiarów reporterskiej spuściźnie, poza reportażami literackimi czy książkami traktującymi o teorii tego gatunku, ma także opowieść o rodzinie, o żoliborskim „Domeczku” i jego mieszkańcach. Ziele na kraterze ${ }^{32}$, bo o tej książce mowa, to przede wszystkim - podobnie jak książka Zaremby Bielawskiego - literacki zapis historii rodziny autora na tle czasów, w jakich przyszło jej żyć. Autor Domu $z$ dwiema wieżami, tak samo jak Melchior Wańkowicz, szczeliny we własnej i cudzej pamięci wypełnia sugestiami, domysłami, wyobrażeniami, przy czym jednocześnie z dziennikarską rzetelnością informuje czytelnika o tych fragmentach opowieści rodzinnej, które rekonstruuje.

Te dwie książki łączy, zresztą nie tylko, wspomniana formuła opowieści. Beata Nowacka pisze:

To dość zastanawiające, że najwybitniejsi polscy reporterzy, filary polskiej szkoły reportażu - Ksawery Pruszyński, Melchior Wańkowicz, Ryszard Kapuściński w dzieciństwie, lub we wczesnej młodości, zostali wygnani ze swoich domów, które z wyroków historii pozostały poza granicami kraju ${ }^{33}$.

Można śmiało powiedzieć, że utrata domu stała się doświadczeniem, które ukształtowało życie zarówno Wańkowicza, jak i Zaremby Bielawskiego i być może z tego powodu obydwaj przywiązują wielką wagę do wszelkich, także tych zawieszonych w odległej historii, relacji rodzinnych. Co ich różni? Opowieść Wańkowicza służy mitologizacji „Domeczku” i rodziny, książka Bielawskiego raczej demitologizuje zarówno rodzinę, jak i polską historię. Zapewne jednak odrębne doświadczenie utraty domu, które mają za sobą obaj reporterzy, wpłynęło na ich losy i twórczość, obu łączy potrzeba zakorzenienia - w życiu najbliższych, historii kraju czy też w losach rodziny ludzkiej $j^{34}$.

Ta potrzeba zakorzenienia, o której pisze Beata Nowacka, niewątpliwie stanowiła ważny powód sięgnięcia przez Zarembę Bielawskiego po pióro, równie ważną wydaje się jednak i ta, która przyczyniła się do powstania Wyspy węży Małgorzaty Szejnert. Impulsem do napisania książki przez reporterkę było odkrycie tajemnicy rodzinnej sprzed lat, i tu historia familijna okazała się doskonałym materiałem, by nie tylko naświetlić dotąd skrywane białe plamy historii, ale i ukazać wstydliwą kartę z dziejów Polskich Sił Zbrojnych na Zachodzie, w dużym stopniu przewartościować, odbrązowić uładzoną i traktowaną jako jednolity konglomerat historię zarówno Drugiej Rzeczpospolitej, jak i udziału Polaków w drugiej wojnie światowej. Podobnie jak Szejnert Zaremba Bielawski zaintrygowany rodzinną historią pełną niedomówień i przemilczeń postanawia przeprowadzić reporterskie śledztwo, by zrekonstruować po latach osobistą historię o rodzicach. O przyczynach,

\footnotetext{
${ }^{32}$ Zob. M. Wańkowicz, Ziele na kraterze, Warszawa 1957.

${ }^{33}$ B. Nowacka, Dom reportera, „Antropos” 2011, nr 16-17, s. 202.

${ }^{34}$ Tamże.
} 
które dały impuls do napisania tej opowieści możemy przeczytać już na początku książki. Bielawski, zastanawiając się nad swoim życiem, moralnością, przeznaczeniem, pisze: „Ale tymczasem muszę wierzyć, że to legendy i zapachy, i wszystkie rzeczy i zdarzenia, które chciano przede mną ukryć, sterują moim tak i nie" ${ }^{\prime 3}$.

Taka deklaracja, jak również początkowe rozdziały, w których odnajdziemy wspomnienia z dzieciństwa i dorastania, życie w cieniu szpitala psychiatrycznego, pierwsze przyjaźnie, miłości, niewątpliwie kierują uwagę czytelnika w stronę autobiograficznej relacji, opowieści inicjacyjnej. Trudno się dziwić wspomnianym krytykom czy badaczom, że zwracali uwagę przede wszystkim na ową postawę autobiograficzną, ale przecież w Domu $z$ dwiema wieżami nie mamy do czynienia, podobnie jak u Wańkowicza czy Miecika, z klasyczną autobiografią, w której postać autora narratora i bohatera oraz jego życie, samopoznanie, dociekanie sensu przeżytych własnych doświadczeń, stanowi zasadniczy motyw książki. Nie jest to bowiem autobiografia reportera, jest to przede wszystkim reportaż literacki, w którym konstrukcja podmiotu opowiadającego nie jest podporządkowana opowieści autobiograficznej, a reporterskiej.

\section{3}

W pierwszej części usiłowałam pokazać, jak Maciej Zaremba Bielawski rozumiał wyjątkowość polskiej szkoły reportażu, pora więc w tym miejscu wskazać w jakim stopniu, moim zdaniem, Dom z dwiema wieżami realizuje model reportażu literackiego. W pierwszej kolejności jednak warto wyszczególnić te cechy, które klasyfikują omawianą tu książkę jako reportaż. W tym celu przywołajmy raz jeszcze fragment wypowiedzi Edyty Żyrek-Horodyskiej, która tak o niej pisze:

Dokumentarna opowieść o losach rodziny autora posiada wiele cech typowych dla dyskursu reportażowego. Cechuje ją rzeczowa faktografia, asertoryczność sądów, czerpanie przez piszącego z licznych źródeł zastanych, aktualność podejmowanej problematyki (relacje polsko-żydowskie, tematyka społecznego wykluczenia ${ }^{36}$ ).

Wymienione przez badaczkę cechy bez wątpienia charakteryzują reportaż, nawet co warto podkreślić - stanowią o reportażowości danego tekstu. Jest to zjawisko ponadgatunkowe, podobnie jak felietonowość czy eseistyczność uobecniające się nie tylko w tekstach, które są gatunkowo reportażami ${ }^{37}$, ale jedynie w reportażu (zarówno tym literackim, jak i publicystycznym) stanowią czynnik konstytuujący. Choć autor na samym początku przewrotnie zaznacza, że: „, $[w]$ szystko w tej książce jest prawdziwe, ale w nic nie trzeba wierzyć" (DW, s. 15), to czytelnik nie

\footnotetext{
${ }^{35}$ M. Szejnert, Wyspa węży, Kraków 2018, s. 15.

${ }^{36}$ E. Żyrek-Horodyska, dz. cyt., s. 142.

${ }^{37}$ Por. E. Balcerzan, Literackość, Toruń 2013, s. 425.
} 
ma wątpliwości, że opowiada on nie tylko prawdziwą historię rodzinną, zaświadczoną osobistą pamięcią ${ }^{38}$. Książka Zaremby Bielawskiego jest świetnie udokumentowana, autor przyjmuje styl kronikarza, który wiedzę na temat przeszłości czerpie zarówno z prywatnych archiwów, jak i z oficjalnych dokumentów. Jak w każdym dobrze napisanym reportażu na końcu książki czytelnik może zapoznać się z bibliografią, z której autor korzystał.

Przypomnijmy jednak, że reporter dostał Nagrodę im. Ryszarda Kapuścińskiego nie za dobrą książkę autobiograficzną, nie za interesujący reportaż, a za autobiograficzny reportaż literacki, za „ocalającą moc literatury" ${ }^{39}$. To literackość tej książki, tak charakterystyczna dla polskiej szkoły reportażu przesądza o jej wartości. Wróćmy więc do jednej z najistotniejszych, charakterystycznych dla niej cech, wspomnianej już konstrukcji podmiotu.

W książce, wydanej niedługo po śmierci Ryszarda Kapuścińskiego, Michał Głowiński poczynił następującą uwagę:

Literackość reportażu to jednak przede wszystkim pewna konstrukcja podmiotu opowiadającego. Reportaż jest pod tym względem gatunkiem na swój sposób paradoksalnym: autor nie może opowiadać o sobie, ale też nie może być nieobecny, nie może uznać, że to, co relacjonuje, dzieje się bez jego udziału, nie może niczego przedstawiać z oddalenia. Musi uczestniczyć. (...) Reporter nie ma prawa rezygnować z mówienia o własnym doświadczeniu. Nie opowiada wprawdzie o sobie, nie umieszcza się na pierwszym planie, ale musi być. Musi odznaczać się wyrazistością, musi charakteryzować się jednostkowymi właściwościami. Bez konkretnego narratora nie ma reportażu ${ }^{40}$.

Także Ryszard Nycz, zastanawiając się nad indeksalnym charakterem dokumentu literackiego, podkreśla ważną rolę ,aktu podmiotowego przyświadczania” w poznawaniu prawdy o faktach. Pisze, iż jest to „prawda jakaś, czyjaś, kiedyś poznana, tak - nie inaczej - artykułowana. Prawda, za którą zawsze coś, lub ktoś stoi; kto „sprawdza sobą” i sobą - swoim życiem, wiedzą, doświadczeniem - owe rzeczy powiedziane nam uprawomocnia”¹. Właśnie z takim typem podmiotowego zaświadczania mamy do czynienia w Domu $z$ dwiema wieżami. To prawda, że książka ta została nasycona autobiografizmem, ale czy Zaremba Bielawski opowiada przede wszystkim o sobie? Nie, bohaterem tej książki jest polska rzeczywistość, powikłane, tragiczne polskie losy, a partie autobiograficzne mają za

${ }^{38} \mathrm{O}$ roli pamięci w Domu $z$ dwiema wieżami pisał Michał Kopczyk. Zob. tenże, dz. cyt.

${ }^{39} \mathrm{Na}$ czwartej stronie okładki książki Macieja Zaremby Bielawskiego możemy przeczytać: „W brawurowo napisanym Domu z dwiema wieżami mieści się wszystko: powaga i groza, humor i autoironia, powściągliwość i liryzm. I ocalająca moc literatury". Zob. tenże, Dom z dwiema wie$\dot{z} a m i$, dz. cyt., okładka, s. 4 .

${ }^{40}$ M. Głowiński, Kapuściński: reportaż jako sztuka [w:] „Życie jest z przenikania...”. Szkice o twórczości Ryszarda Kapuścińnkiego, red. B. Wróblewski, Warszawa 2008, s. 64.

${ }^{41}$ R. Nycz, Tekstowy świat. Poststrukturalizm a wiedza o literaturze, Kraków 2000, s. 320. 
zadanie uwiarygodnienie zarówno treści opowiadanej historii, jak i jej sensu. Jak to ładnie ujął Leszek Szaruga chodzi o „przedstawienie »mojego świata«, którego realność gwarantowana jest przez realność opowiadacza"42.

Drugą, ważną cechą reportażu literackiego, jest poznawanie świata, ale przede wszystkim jego rozumienie, a także wyjaśnienie rzeczywistości, o której autor opowiada. W powszechnej świadomości reporter pełni zazwyczaj funkcję przewodnika, nauczyciela, osoby, która dzięki zdobytej wiedzy i doświadczeniu wie lepiej, rozumie trafniej. W Domu $z$ dwiema wieżami Zaremba Bielawski próbuje rozpracować nie tylko swoje dziedzictwo, chce zrozumieć przede wszystkim świat, w którym przyszło żyć jego bliskim. Wykorzystuje opowieść o sobie i o swoich rodzicach, by za jej pomocą opowiedzieć o rzeczach daleko wykraczających poza prywatną sferę. Opowieść o matce to próba uchwycenia, przeniknięcia zjawiska jakim byl/jest antysemityzm w polskim wydaniu, ale przede wszystkim, to próba zrozumienia tego, jak być obcym we własnym kraju (DW, s. 123). Te dwa problemy wzajemnie się oświetlają. Jak w klasycznym reportażu literackim, Zaremba Bielawski korzysta z wiedzy uzupełniającej, wspomagającej. Żeby zrozumieć sytuację swojej matki w owym czasie, sięga po teksty z prasy lat dwudziestych $\mathrm{XX}$ wieku, przywołuje fragmenty biografii i tekstów Romana Dmowskiego, opowiada o życiu Antoniego Słonimskiego. „[P]potrzebuję Antoniego Słonimskiego, żeby zrozumieć swój los. To znaczy, żeby zrozumieć moją mamę" (DW, s. 121) - pisze, cytując wybrane teksty poety. Pogłębiona wiedza jest w reportażu zawsze najlepszym sprzymierzeńcem objaśniania świata.

Dom $z$ dwiema wieżami to metaforyczny tytul, w którym owe wieże mają stanowić filary dziedzictwa, tożsamości, na którą składa się los żydowskich przodków ze strony reportera i szlacheckich krewnych ojca Oskara. Metaforę dwóch wież można też odczytać w odniesieniu do samego procesu pisania, do wykorzystania przez autora, w bardziej lub mniej świadomy sposób, rozwiązań wypracowanych przez polską szkołę reportażu. Widać bowiem w książce Zaremby Bielawskiego wpływ dwóch nurtów, jakie ukształtowały polski reportaż literacki. Na ich dominację wskazywał już Zygmunt Ziątek w artykule: Reporterzy wobec historii, gdzie analizował różnice w pisarstwie Hanny Krall i Ryszarda Kapuścińskiego. Charakteryzowała je także sama autorka Hipno$z y$, konstatując: „Są dwa sposoby pisania o świecie, poprzez szeroką, rozległą panoramę, poprzez dzieje narodów, wojny i rewolucje, jak robi to Ryszard Ka-

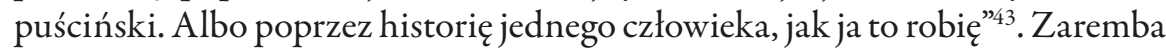

${ }^{42}$ L. Szaruga, W stronę metaliteratury. Dziennik intelektualny po 1989 roku jako obrona podmiotu na tle tradycji powojennej [w:] Podmiot w literaturze polskiej po 1989 roku. Antropologiczne aspekty konstrukcji, red. Ż. Nalewajk, Warszawa 2011, s. 64.

${ }^{43} \mathrm{~J}$. Antczak, Reporterka. Rozmowy z Hanna Krall, Warszawa 2007, s. 45. Świadomość istotnych różnic w twórczości reportażowej miał także Wojciech Jagielski. W jednym z wywiadów powiedział: „W »Wyborczej《 były jego [reportażu - dop. M.W.] dwie szkoły. Jedna była szkołą Kapuścińskiego, druga Hanny Krall. I myślę, że większość reporterów »Wyborczej« jest ze szkoły 
Bielawski jest pilnym uczniem obydwojga. Od Hanny Krall nauczył się trudnego pisania o losie pojedynczego człowieka, uwikłanego w okrucieństwa historii, schwytanego w jej miażdżące mechanizmy, upodlanego i unicestwianego przez nią. Przywołajmy fragment, w którym reporter opowiada o wojennych losach matki:

Lila zakłada opaskę z czerwonym krzyżem, bierze ich pod ręce i rusza pod prąd uciekających Żydów, a potem w stronę prześladowców. Widzę to z dachów. Widzę, jak potykają się na bruku śliskim od krwi i substancji mózgu, widzę jak fala istot zbrojnych w pałki i siekiery rozstępuje się przed trojgiem, przepływa wokół nich i znika (DW, s. 209).

Z premedytacją Zaremba Bielawski wybiera ten arcyliteracki sposób pisania. Za pomocą kilku słów kluczy, kilku drobnych obserwacji wyprowadzonych z perspektywy narratora, który, bądź to na skutek imaginacji, czy raczej ducha unoszącego się ponad Krzemieńcem, zarysowuje sytuację pogromu. Oszczędny, lakoniczny styl, oparty na celowych powtórzeniach, zaskakujących zestawieniach, także krótkie, zwięzłe zdania, które nie opowiadają o emocjach, ale mają je wzbudzać - to atrybuty prozy Hanny Krall.

Podobnie jak u autorki Hipnozy, opowieściom Zaremby Bielawskiego o koszmarze Holokaustu często towarzyszy niewiedza: „Istnieją trzy wersje śmierci dziadka” - pisze reporter (DW, s. 217), „Nic nie wiadomo o jego ostatnim czasie” (DW, s. 218), „Mógłbym dopytać starych ludzi, kim był, ale nie chcę budzić demonów" (DW, s. 219). To podobny zabieg, jaki spotykamy w tekstach autorki Dowodów na istnienie, to trafnie odczytana istota literackiego świadczenia, która jest nieodłącznym atrybutem tekstów Hanny Krall. Maria Delaperrière pisała o sednie takiego świadczenia, że: „ujawnia niewystarczalność narracji linearnej, przeciwstawiając jej fragment, niedopowiedzenie, białe plamy przemilczeń, często będące obietnicą nigdy nieosiągalnej prawdy"44

Badacze często podkreślają uważność Hanny Krall na detal, drobiazg, a także skupienie na tym, co konkretne, namacalne. Kiedy w Hipnozie opowiada o ciałach leżących na ulicach getta, przykrytych gazetami, autorkę zaczyna nurtować pytanie, jakie to były gazety ${ }^{45}$. Zaremba Bielawski również ma świadomość wagi szczegółu. Przywołajmy kolejny fragment Domu z dwiema wieżami:

chłopak od promu puka się w głowę. Sama panienka widzi. Czarny nurt i kra wali. „To sprawa najwyższej wagi”, mówi Lila, „moja matka musi mieć jajka”. I przeprawiają się tam i z powrotem, oboje równie wystraszeni (DW, s. 222).

Krall. Mnie zdecydowanie bliższy był Kapuściński”. Z Wojciechem Jagielskim Rozmawiat Pawet Średzinsski, http://afryka.org/afryka/wywiad--wojciech-jagielski,news, dostęp: 24.05.2019.

${ }^{44}$ M. Delaperrière, Świadectwo jako problem literacki, „Teksty Drugie” 2006, nr 3, s. 70.

${ }^{45}$ Zob. H. Krall, Hipnoza, Warszawa 1989, s. 13. 
Opowieść o zdobywaniu wielkanocnych jajek, czy o gladiolach, które Lila kupiła zakochanemu w niej chłopakowi (DW, s. 221), a także kolor munduru (DW, s. 226), czy lampki przy sofie (DW, s. 228), detaliczny opis pokoju (DW, s. 226) i wytłumaczenie, na czym polegało rozjaśnianie włosów (DW, s. 230), te drobiazgi są niezwykle istotną częścią mikroświata matki reportera, tak jakby autor chciał nam zwrócić uwagę, że w przywoływaniu świata, którego już nie ma, $\mathrm{w}$ nieustannym zmaganiu z zapomnieniem, wszystko staje się ważne.

Twórczość Hanny Krall zainspirowała Zarembę Bielawskiego, by przejąć kolejną "pałeczkę w procesie pamiętania" ", by poprzez wybrane informacje o zdarzeniach, skupieniu na szczególe i układanie wycyzelowanych zdań stworzyć zapis pojedynczych losów, ale i bólu ludzkiego doświadczenia. Spróbujmy w takim razie zastanowić się, co ważnego i wartego wykorzystania dostrzegł autor Domu $z$ dwiema wieżami w twórczości Ryszarda Kapuścińskiego. Najogólniej rzecz ujmując, będzie to fascynacja historią, a dokładniej procesem, w którym jednostkowe działania przekształcają się w wymiarze zbiorowym w mechanizmy wielkiej historii. Ta zależność intrygowała Zarembę Bielawskiego. We wstępie do wspomnianej już antologii odniósł się do wypowiedzi Adama Michnika, w której redaktor „Gazety Wyborczej” deklarował, że reportaż powinien być zawsze po stronie tego, co jednostkowe i konkretne, wyzwolony od doktryn, uogólnień i terroru Wielkich Liczb ${ }^{47}$. Autor Higienistów pisał:

W tym miejscu ktoś mógłby wtrącić, że renesansowe przekonanie o pojedynczym ludzkim losie jako mierze społeczeństwa może utrudnić spostrzeżenie wielkich linii historycznych i struktur, których potrzebujemy, by rozumieć świat. Nie zgodzę się̧.

Zaremba Bielawski nie zgadzał się z Michnikiem, ponieważ był uważnym czytelnikiem Kapuścińskiego i widział, że jest możliwe pogodzenie tych dwóch, pozornie odległych, tendencji: ukazywania niemożności uchwycenia jedności, ciągłości oraz jednocześnie uparte poszukiwanie wyjścia z tego impasu, poprzez poszukiwanie ogólności, całości. W Domu z dwiema wieżami możemy odnaleźć na przykład taki fragment:

Kiedy Lila kończy trzy lata, wybucha bomba przed domem rektora Uniwersytetu Jagiellońskiego. Winni nie zostają wykryci. Lecz mało kto ma wątpliwości, kim są.

${ }^{46}$ Wypowiedź Hanny Krall podczas otrzymania w 2008 roku Nagrody im. Ricardy Huch, https://www.dw.com/pl/niemiecka-nagroda-dla-hanny-krall/a-3689155, dostęp: 3.10.2008.

${ }^{47}$ Adam Michnik we wstępie do zbioru reportaży tak widzi istotę pisarstwa reportażowego: „Reportaż rejestruje to, co jednostkowe, niepowtarzalne, intymnie przeżyte. Gdy wszyscy badają świat Wielkich Liczb roczników statystycznych, »wojen na górze «, reporter pochyla się nad każdym z indywidualnych marzeń i dramatów”. A. Michnik, Wstęp [do:] Kraj raj. Piszą reporterzy „Gazety”, Warszawa 1993, s. 11.

${ }^{48}$ M. Zaremba Bielawski, Dziennikarz jest świadkiem, dz. cyt., s. 12-13. 
Rektor Natanson nie ma zamiaru dyskryminować żydowskich studentów na uczelni. Lila ma pięć lat, wynotowuję typowe hasło z „Kuriera Poznańskiego”: „Każdy Żyd w kraju to wróg w granicach państwa”. Gdy Lila kończy sześć lat ci, którzy tak uważają, zdobywają w Krzeszowicach, gdzie mieszka, bezwzględną większość (DW, s. 140-141).

Ta umiejętność nadawania zdarzeniom, gestom, wypowiedziom znaczenia przez umieszczanie ich we właściwym kontekście historycznym, etycznym czy obyczajowym czyni z Domu z dwiema wieżami reportaż literacki. Zaremba Bielawski nie ostrzy swojego publicystycznego pióra, by piętnować polski antysemityzm ${ }^{49}$. Mógłby, miałby do tego pełne prawo, ale woli ukazać ludzki wymiar historii. Historia ma w Domu z dwiema wieżami wymiar podmiotowy, nie jest tu jakimś strasznym, a zarazem nieuchwytnym i niedefiniowalnym abstraktem, ale jawi się jako konkretna i dająca się sprecyzować relacja człowieka do człowieka. Kończąc opowieść, reporter stwierdza: „Kiedy towarzysz Gomułka w 1968 roku rujnuje naszą rodzinę, ma po swojej stronie wszystkie moce. Historię i biologię, milczenie i niepamięć. Dosyć to nazwać losem” (DW, s. 280).

Ryszard Kapuściński nauczył polskich reporterów, że nie można pisać o zjawiskach, które obserwują, bez odwołania się do wiedzy historycznej. Obaj reporterzy, szukając przede wszystkim okruchów prawdy o współczesności, są świadomi, iż uchwycić ją można jedynie na sposób paradoksalny - w ciągu zdarzeń, kolei losów ludzi, narodów, a współczesna rzeczywistość jest dla autorów realizacją pewnych oznak i symptomów, które można odczytać w przeszłości. Jest to też bardzo uniwersalna opowieść o historii „spuszczonej z łańcucha” i jej niszczycielskiej mocy, a dzięki antropologizacji refleksji nad historią, jaką znajdujemy w Domu z dwiema wieżami, nabiera ona wyjątkowego znaczenia, pozwala nie tylko wyjaśnić dzieje, ale także je zrozumieć.

Warto na marginesie dopowiedzieć, że w ostatnich latach możemy zaobserwować coraz większą liczbę dobrze napisanych reportaży literackich, których celem jest poruszanie trudnych, czasem bardzo bolesnych tematów naszej najnowszej historii. Stanowią one bardzo ważny kontrapunkt dla coraz bardziej ujednolicanej polityki historycznej, nie pozwalając, by została ona domknięta. Dom $z$ dwiema wieżami podobnie jak książki Hanny Krall, Małgorzaty Szejnert, Cezarego Łazarewicza, Włodzimierz Nowaka czy Pawła Smoleńskiego odkrywają to, co często zepchnięte było w społeczne zapomnienie, stanowiło rodzaj pamięci - jak trafnie określa ją Jacek Żakowski - przemilczanej, czy raczej uciszonej ${ }^{50}$.

${ }^{49}$ Mając świadomość, że zwrot „polski antysemityzm” jest na granicy generalizacji, używam go zgodnie z intencją Zaremby Bielawskiego, który pisze: „»Polski antysemityzm «, tak należy mówić. Nie » antysemityzm w Polsce «". Zupełnie własna paranoja, uszyta na miarę dla Polski” (DW, s. 148).

${ }^{50}$ Por. J.ZZakowski, Rewanż pamięci, Warszawa 2002, s. 15-16. Książka Zaremby Bielawskiego jest bardzo interesująca pod względem historiograficznym, bo autorowi udaje się wypełnić białe plamy w historii Polski, a konkretnie, w historii Związku Lekarzy Państwa Polskiego i antysemickich 
Na koniec jeszcze jedna, istotna kwestia. Otóż, moim zdaniem, kluczem do wyodrębnienia reportażu literackiego jest postawa humanistyczna ${ }^{51}$. Rozumiem ją nie tylko jako odpowiedzialność za słowo, ale przede wszystkim jako refleksję nad kondycją człowieka i świata, a także nad własnym stosunkiem do tematu, jako świadome zadawanie pytań o miejsce i rolę wartości w świecie ${ }^{52}$. Kończąc opowieść o bytności ojca w oflagu, autor Domu z dwiema wieżami, pisze:

Jednak odkąd pamiętam, zawsze fascynowały mnie archaiczne wyjątki; gdy ktoś sprzeciwia się barbarzyńskiemu porządkowi - nie z powodu współczucia czy wrodzonej dobroci - tylko dlatego, że hołduje jakiejś zmurszałej tradycji (DW, s. 292).

Zaremba Bielawski w autobiograficznej opowieści próbuje poskładać zupełnie niekompatybilne losy swoich bohaterów, ale przede wszystkim światy wartości, w których przyszło mu dorastać. Z jednej strony to traumatyczny lęk matki i jej świat, zbudowany jak pieczołowicie odgrywany spektakl, na niszczącej wszelkie relacje tajemnicy, z drugiej rycerskie wartości ojca i przywiązanie do zasad i zwyczajów obowiązujących w przedwojennej rzeczywistości. Refleksja, jaka wyłania się z wręcz nieprawdopodobnego zderzenia tych dwóch światów wartości, to jeden z najważniejszych problemów podjętych przez autora. Być może w tym zestawieniu możemy szukać odpowiedzi na pytanie o źródła współczesnych podziałów Polski. Literackość Domu $z$ dwiema wieżami to także wielowymiarowy namysł nad losem polskich Żydów, antysemityzmem, ale głównie nad pamięcią. Zaremba Bielawski, badając teksty kultury z ostatnich siedemdziesięciu lat, nie tylko sprawdzil, jak funkcjonuje pamięć i niepamięć o polsko-żydowskich relacjach $^{53}$, jakie mity i które stereotypy na temat wspólnoty powielamy, ale przede wszystkim zaproponował refleksję nad źródłami ideologii narodowych $\mathrm{i}$ ich niszczycielskiej siły oddziaływania.

\section{Bibliografia}

Antczak J., Reporterka. Rozmowy z Hanna Krall, Warszawa 2007.

Balcerzan E., Literackość, Toruń 2013.

Czego nam zazdroszcza Szwedzi?, rozmowę z Maciejem Zaremba Bielawskim przepro-

wadzit G. Sokót, „Gazeta Wyborcza” 2003, nr 272 [dodatek: „Książki”, nr 11(2)].

Delaperrière M., Świadectwo jako problem literacki, „Teksty Drugie” 2006, nr 3.

zapisów w statucie tej organizacji z 1937 roku, czy też w historii życia codziennego w oflagach i stalagach, wskazując na różnicę w funkcjonowaniu tych obozów jenieckich.

${ }^{51}$ Zob. C. Niedzielski, O teoretycznoliterackich tradycjach prozy dokumentalnej (podróż - powieść - reportaż), Toruń 1966.

${ }^{52}$ Pisałam o postawie humanistycznej w książce: M. Wiszniowska, dz. cyt.

${ }^{53} \mathrm{Na}$ kwestie pamięci w Domu $z$ dwiema wieżami zwrócił uwagę także Maciej Duda. Zob. tenże, Rzeczy bardzo smutne, „Czas Kultury” 2019, nr 1. 
Domańska E., Mikrohistorie. Spotkania w międzyświatach, Poznań 2005.

Duda M., Rzeczy bardzo smutne, „Czas Kultury” 2019, nr 1.

Fiedorczuk J., Tylko trzy stowa, http://www.kulturalna.warszawa.pl/kapuscinski,6,11027. html, dostęp: 17.03.2021.

Frukacz K., Szwedzki Polak - polski Szwed. Maciej Zaremba Bielawski wobec polskości i polskiej szkoty reportażu [w:] Literatura polska w świecie, t. 7: Reportaż w'wiecie. Światowość reportażu, red. K. Frukacz, Katowice 2019.

Głowiński M., Kapuściński: reportażjako sztuka [w:] „Życiejestzprzenikania...”. Szkice o twórczości Ryszarda Kapuścińskiego, red. B. Wróblewski, Warszawa 2008.

Hugo-Bader J., W rajskiej dolinie wśród zielska, Warszawa 2002.

Jagielski W., Wieże z kamienia, Warszawa 2004.

Kapuściński R., Imperium, Warszawa 1993.

Kopczyk M., Hermeneutyka pamięci. O „Domu z dwiema wieżami” Macieja Zaremby Bielawskiego, „Białostockie Studia Literaturoznawcze” 2020, nr 17.

Krakowiak M., Neofabulacja w pisarstwie polskich reportażystów („Wszystkie wojny Lary” Wojciecha Jagielskiego i „Synapsy Marii H.” Hanny Krall) (nieopublikowane).

Krall H., Hipnoza, Warszawa 1989.

Michnik A., Wstęp [do:] Kraj raj. Piszq reporterzy „Gazety”, Warszawa 1993.

Miecik I.T., Sezon na stoneczniki, Warszawa 2015.

Niedzielski C., O teoretycznoliterackich tradycjach prozy dokumentalnej (podróż - powieść - reportaż), Toruń 1966.

Nowacka B., Dom reportera, „Antropos” 2011, nr 16-17.

Nowak W., Obwód gtowy, Wołowiec 2007.

Nycz R., Tekstowy świat. Poststrukturalizm a wiedza o literaturze, Kraków 2000.

Obirek S., Dom z dwiema wieżami - ksiązka na czasie, https://studioopinii.pl/archiwa/199021, dostęp: 20.06.2020.

Ostałowska L., Cygan to Cygan, Wołowiec 2012.

Polska to europejski fenomen. W żadnym innym kraju reportaż nie jest tak bardzo sexy. Dlaczego? Z Maciejem Zaremba Bielawskim rozmawia Anna S. Dębowska, „Gazeta Wyborcza”, 23.05.2019.

Portret Badera. Z Jackiem Hugo-Baderem rozmawia Piotr Brysacz [w:] Patrzac na Wschód. Przestrzeń, cztowiek, mistycyzm, Białystok 2013.

Proszenie tracaćmnie tokciem w bok. Z Maciejem Zarembą Bielawskim rozmawia A. Szytto, „Gazeta Wyborcza”, 10.03.2016 [dodatek: „Duży Format”].

Szaruga L., W strone metaliteratury. Dziennik intelektualny po 1989 roku jako obrona podmiotu na tle tradycji powojennej [w:] Podmiot w literaturze polskiejpo 1989 roku. Antropologiczne aspekty konstrukcji, red. Ż. Nalewajk, Warszawa 2011.

Szczygieł M., Gottland, Wołowiec 2006.

Szejnert M., Wyspa węży, Kraków 2018.

Tochman W., Jakbyś kamień jadta, Sejny 2002.

Tochman W., Schodów się nie pali, Kraków 2000.

Wańkowicz M., Ziele na kraterze, Warszawa 1957. 
Wicha M., Mama powiedziata: „Wyjeżdzamy. Jestem Żydówkq̨" Nowa ksiażka Zaremby Bielawskiego jest jak operacja na samym sobie, „Gazeta Wyborcza”, 4.12.2018.

Wiszniowska M., Zobaczyć - opisać - zrozumieć. Polskie reportaże literackie o rosyjskim imperium, Katowice 2017.

Wypowiedź Hanny Krall, https://www.dw.com/pl/niemiecka-nagroda-dla-hanny-krall/a-3689155, dostęp: 3.10.2008.

Wypowiedź Macieja Zaremby Bielawskiego, https://wyborcza.pl/7,75517,24816362, nagroda-kapuscinskiego-2019-dla-macieja-zaremby-bielawskiego.html, dostęp: 24.05.2019.

Z Wojciechem Jagielskim Rozmawiat Pawet Średziński, http://afryka.org/afryka/wywiad--wojciech-jagielski,news, dostęp: 24.05.2019.

Zaremba Bielawski M., Dom z dwiema wieżami, tłum. M. Kalinowski, Kraków 2018. Zaremba Bielawski M., Dziennikarz jest świadkiem, tłum. G. Sokół, „Tygodnik Powszechny” 2009, nr 23 [dodatek: „Festiwal Conrada 2009”].

Zaremba Bielawski M., Higieniści. Z dziejów engeniki, tłum. W. Chudoba, Wołowiec 2011.

Zaremba Bielawski M., Leśna mafia. Szwedzki thriller ekologiczny, ttum. M. Wasilewska-Chmura, Warszawa 2014.

Zaremba Bielawski M., Polski hydraulik i inne opowieści ze Szwecji, tłum. W. Chudoba, J. Rost, A. Topaczewska, K. Tubylewicz, Wołowiec 2008; Warszawa 2013.

Żakowski J., Rewanż pamięci, Warszawa 2002.

Żyrek-Horodyska E., Reportażowa saga rodzinna. Fuzja gatunków i dziennikarska archiwistyka, „Zeszyty Naukowe KUL” 2019, nr 4. 